\title{
RyR1-related myopathy mutations in ATP and calcium binding sites impair channel regulation
}

\author{
Qi Yuan ${ }^{1}$, Haikel Dridi ${ }^{1}$, Oliver B. Clarke ${ }^{1,2,3}$, Steven Reiken ${ }^{1}$, Zephan Melville ${ }^{1}$, Anetta Wronska ${ }^{1}$, \\ Alexander Kushnir ${ }^{1}$, Ran Zalk ${ }^{4}$, Leah Sittenfeld ${ }^{1}$ and Andrew R. Marks ${ }^{1,3^{*}}$
}

\begin{abstract}
The type 1 ryanodine receptor (RyR1) is an intracellular calcium $\left(\mathrm{Ca}^{2+}\right)$ release channel on the sarcoplasmic/endoplasmic reticulum that is required for skeletal muscle contraction. RyR1 channel activity is modulated by ligands, including the activators $\mathrm{Ca}^{2+}$ and ATP. Patients with inherited mutations in RyR1 may exhibit muscle weakness as part of a heterogeneous, complex disorder known as RYR1-related myopathy (RYR1-RM) or more recently termed RYR1-related disorders (RYR1-RD). Guided by high-resolution structures of skeletal muscle RyR1, obtained using cryogenic electron microscopy, we introduced mutations into putative $\mathrm{Ca}^{2+}$ and ATP binding sites and studied the function of the resulting mutant channels. These mutations confirmed the functional significance of the $\mathrm{Ca}^{2+}$ and ATP binding sites identified by structural studies based on the effects on channel regulation. Under normal conditions, $\mathrm{Ca}^{2+}$ activates RyR1 at low concentrations $(\mu \mathrm{M})$ and inhibits it at high concentrations $(\mathrm{mM})$. Mutations in the $\mathrm{Ca}^{2+}$-binding site impaired both activating and inhibitory regulation of the channel, suggesting a single site for both high and low affinity $\mathrm{Ca}^{2+}$-dependent regulation of RyR1 function. Mutation of residues that interact with the adenine ring of ATP abrogated ATP binding to the channel, whereas mutating residues that interact with the triphosphate tail only affected the degree of activation. In addition, patients with mutations at the $\mathrm{Ca}^{2+}$ or ATP binding sites suffer from muscle weakness, therefore impaired RyR1 channel regulation by either $\mathrm{Ca}^{2+}$ or ATP may contribute to the pathophysiology of RYRT-RM in some patients.
\end{abstract}

\section{Significance}

The ryanodine receptor/calcium release channel (RyR1) is required for skeletal muscle excitation-contraction (EC) coupling. Mutations in RyR1 that render the channel leaky (unable to close properly) to calcium $\left(\mathrm{Ca}^{2+}\right)$ cause an inherited form of muscle weakness known as RyR1related disorders (RyR1-RD). Using the high-resolution RyR1 structure solved in our laboratory we identified binding sites for the channel activators $\mathrm{Ca}^{2+}$ and ATP.

\footnotetext{
*Correspondence: arm42@columbia.edu

${ }^{3}$ Wu Center for Molecular Cardiology, Vagelos College of Physicians and Surgeons of Columbia University, Russ Berrie Medical Science Pavilion, 1150 St. Nicholas Avenue, New York, NY 10032, USA

Full list of author information is available at the end of the article
}

Mutagenesis of these sites combined with functional studies confirmed that they are indeed the key ligand binding sites. Both the ATP and $\mathrm{Ca}^{2+}$ sites are involved in disease-causing mutations that alter the response of the channel to these physiological activators and likely contribute to the pathophysiology of RyR1-RD.

\section{Introduction}

Calcium is a vital second messenger $[6,38]$ that regulates numerous cellular signaling pathways, including muscle contraction [38], hormone secretion [57], and synaptic transmission [64]. Ryanodine receptors (RyRs) are located on the sarcoplasmic/endoplasmic reticulum (SR/ER) and mediate the release of $\mathrm{Ca}^{2+}$ from original author(s) and the source, provide a link to the Creative Commons licence, and indicate if changes were made. The images or other third party material in this article are included in the article's Creative Commons licence, unless indicated otherwise in a credit line to the material. If material is not included in the article's Creative Commons licence and your intended use is not permitted by statutory regulation or exceeds the permitted use, you will need to obtain permission directly from the copyright holder. To view a copy of this licence, visit http://creativecommons.org/licenses/by/4.0/. The Creative Commons Public Domain Dedication waiver (http://creativeco mmons.org/publicdomain/zero/1.0/) applies to the data made available in this article, unless otherwise stated in a credit line to the data. 
intracellular stores [56]. The three mammalian isoforms, RyR1, RyR2, and RyR3, share approximately $70 \%$ sequence identity. RyR 1 and RyR 2 are widely expressed and are the major SR $\mathrm{Ca}^{2+}$ release channels in skeletal and cardiac muscles, respectively [54, 77]. RyR3 was originally found in the brain, but it is also expressed in other tissues [58].

RyR1 is required for excitation-contraction (EC) coupling in skeletal muscle. RyR1 is a homotetramer comprised of four $565 \mathrm{kDa}$ protomers and as such is the largest known ion channel. In addition, regulatory and targeting proteins for enzymes including protein kinase A (PKA) and CaM kinase II (CAMKII), are associated with the channel and regulate its function [41, 45].

RYR1-related myopathies (RYR1-RM), or as recently proposed RYR1-related disorders (RyR1-RD) [31], are rare, inherited disorders, the prevalence of which have likely been underestimated at 1:90,000 individuals [1]. Indeed, RYR1-RD is the most common form of non-dystrophic muscle disease and includes individuals with malignant hyperthermia susceptibility that affects 1:3000-1:8500 and possibly as many as 1 in 400 [31]. RYR1-RD exhibits both autosomal dominant and recessive inheritance as well as de novo occurrences. RYR1-RD is characterized by pleotropic clinical presentations ranging from mild to severe muscle weakness, and moderate to severe respiratory insufficiency, which is more often apparent in recessive cases. Some mutations in RYR1 (19q13.2) result in leaky channels that promote muscle weakness and damage in RyR1-RD patients [27]. Although there are currently no approved treatments, a clinical trial using a novel Rycal drug that fixes the leak in RyR1 channels is currently underway at the NIH (NCT04141670).

The RyR1 macromolecular complex includes calstabin $[43,45,69,74]$, PKA [52], CaMKIIס [26, 70], the phosphatases PP1 and PP2A [15, 42], the phosphodiesterase PDE4D3 [32, 57], sorcin [19], calmodulin [49, 51, 53, 66, 78], triadin [55], junction [33], and calsequestrin [4]. RyR channels are regulated by posttranslational modifications including phosphorylation [27, 44, 45], oxidation $[2,59,60]$, and nitrosylation [5]. RyR channels exhibit a bell-shaped response to cytosolic $\mathrm{Ca}^{2+}$, with activation at micromolar levels and inhibition at millimolar concentrations [7]. ATP is a potent activator of RyR [48] and millimolar ATP concentrations enhance $\mathrm{Ca}^{2+}$-dependent activation of RyR1, manifested as increased open probability (Po) [8, 17, 30, 50, 63, 65]. In disease states, RyR channels may exhibit a stressed-induced leak that contributes to the pathophysiology of heart failure [22, 39, 40, 45], cardiac arrhythmias [69], diabetes [57], muscular dystrophy [3], age-dependent loss of muscle function [2], cancer-associated muscle weakness [68], post-traumatic stress disorder [36], Alzheimer's Disease [9, 28], and Huntington's Disease [16].

In 2015, three cryogenic electron microscopy (cryoEM) studies, including our own, described the highresolution architecture of the closed state of RyR1 [18, 73, 76], revealing that RyR1 belongs to the six transmembrane (6TM) cation channel family. As opposed to most members of the 6TM family, RyR is not voltage gated; however, it contains an evolutionarily conserved pseudo-voltage-sensor domain (pVSD) [76] which lacks the positively charged residues present in voltage-gated channels. We also solved the structure of the open state of RyR1, activated by $\mathrm{Ca}^{2+}$, ATP, and caffeine, revealing the structural basis of channel gating and liganddependent activation of RyR1 [14]. The cytosolic shell of RyR is composed of alpha-solenoid repeats, including two N-terminal beta-trefoil domains (NTD-A and NTD-B) [67], three SPRY domains (SPRY1-SPRY3) [29], two pairs of RYR repeats (RY1\&2 and RY3\&4) [61, 75], and a pair of EF-hands (EF1\&2) [71] inserted in the core solenoid [76]. The activation domain contains a thumb and forefinger motif (TaF), which clamps the zinc fingercontaining C-terminal domain (CTD) and provides allosteric coupling between the movement of the cytosolic shell and dilation of the pore aperture. The core solenoid (C-Sol), which is part of the activation domain, links the pore domain to the shell. Binding sites for $\mathrm{Ca}^{2+}$, caffeine, and ATP were identified at interdomain interfaces of the C-terminal domain and the transmembrane domain [14] where they likely stabilize interdomain interactions and amplify the effects of $\mathrm{Ca}^{2+}$ binding on the gating of the channel pore (Fig. 1).

Our previous work examined the pathophysiological mechanisms underlying RyR1-RD [27]. The present study extends these observations at the atomic level by focusing on structure/function studies of the ATP and $\mathrm{Ca}^{2+}$ binding sites and disease causing mutations that affect these sites in patients with RyR1-myopathy. In the present study, we used site-directed mutagenesis to assess the functional importance of the ATP and $\mathrm{Ca}^{2+}$ binding sites that we previously identified using cryo-EM. Moreover, RyR1 channel mutations found at the $\mathrm{Ca}^{2+}$ and ATP binding sites of patients with RYR1-RD resulted in defective regulation by $\mathrm{Ca}^{2+}$ and ATP that may contribute to muscle weakness in RYR1-RD patients.

\section{Results}

Architecture and function of the RyR1 ATP binding site

The ATP binding site of RyR1 is located at the junction of the cytoplasmic extension of S6 (S6c) tranmembrane helix and the CTD [14]. Based on the structure, T4979 of the CTD contributes to the adenine ring binding site, and the positively charged K4211, K4214, and R4215 


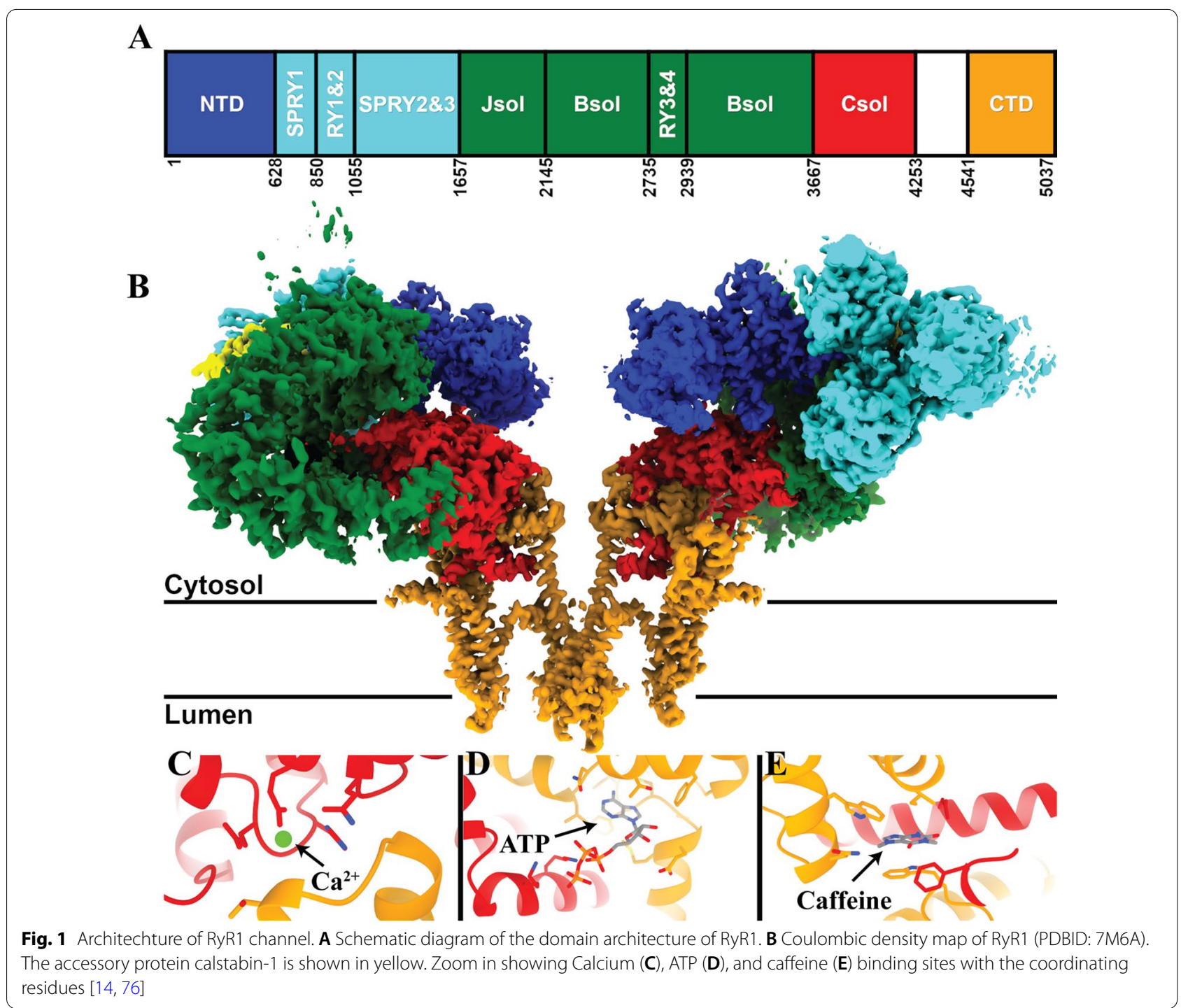

residues of the TaF interact with the triphosphate tail of ATP (Fig. 2A). Based on this model, we hypothesized that mutation of T4979 would reduce ATP binding to RyR1, whereas mutation of K4211, K4214, and R4215 would reduce ATP-dependent activation of RyR1, since ADP and AMP are less effective activators of RyR1 [10, 30].

To assess the functional effects of the ATP binding site. T4979 was mutated to phenylalanine (T4979F), near the adenine ring of ATP, and a triple mutant of K4211/ K4214/R4215, each to serine, near the triphosphate tail of ATP was generated. These mutants were made in recombinant rabbit RyR1 and expressed in HEK293 cells. To assess the effects of these mutations, $\left[\alpha-{ }^{32} \mathrm{P}\right]$-ATP binding, $\left[{ }^{3} \mathrm{H}\right]$-ryanodine binding, which is a surrogate measure of channel activity, and single channel recordings in planar lipid bilayers were performed. The RyR1 T4979F mutant channel exhibited reduced $\left[\alpha-{ }^{32} \mathrm{P}\right]$-ATP binding, with a Bmax of $2.5 \pm 0.25 \mathrm{pmol} \mathrm{ATP} / \mathrm{pmol}$ RyR1 compared to a Bmax of $8.0 \pm 0.77 \mathrm{pmol} A T P / \mathrm{pmol}$ RyR1 for WT RyR1. These data confirm that T4979 is a critical residue for ATP binding to RyR1. Furthermore, the Bmax of 8 suggests that there is likely a second ATP binding site in RyR1 with two molecules of ATP are binding per protomer of the homotetrameric channel. In contrast, the K4211S/K4214S/R4215S mutant channel exhibited normal $\left[\alpha{ }^{32} \mathrm{P}\right]$-ATP binding to RyR1 (Fig. 2B), indicating that the complete triphosphate tail is not required for ATP binding to RyR1.

We then used $\left[{ }^{3} \mathrm{H}\right]$-ryanodine binding to further evaluate activation of RyR1 by ATP binding. Ryanodine binds to pore of the RyR1 channel in the open state $[12,14]$ and therefore binding can be used as an 

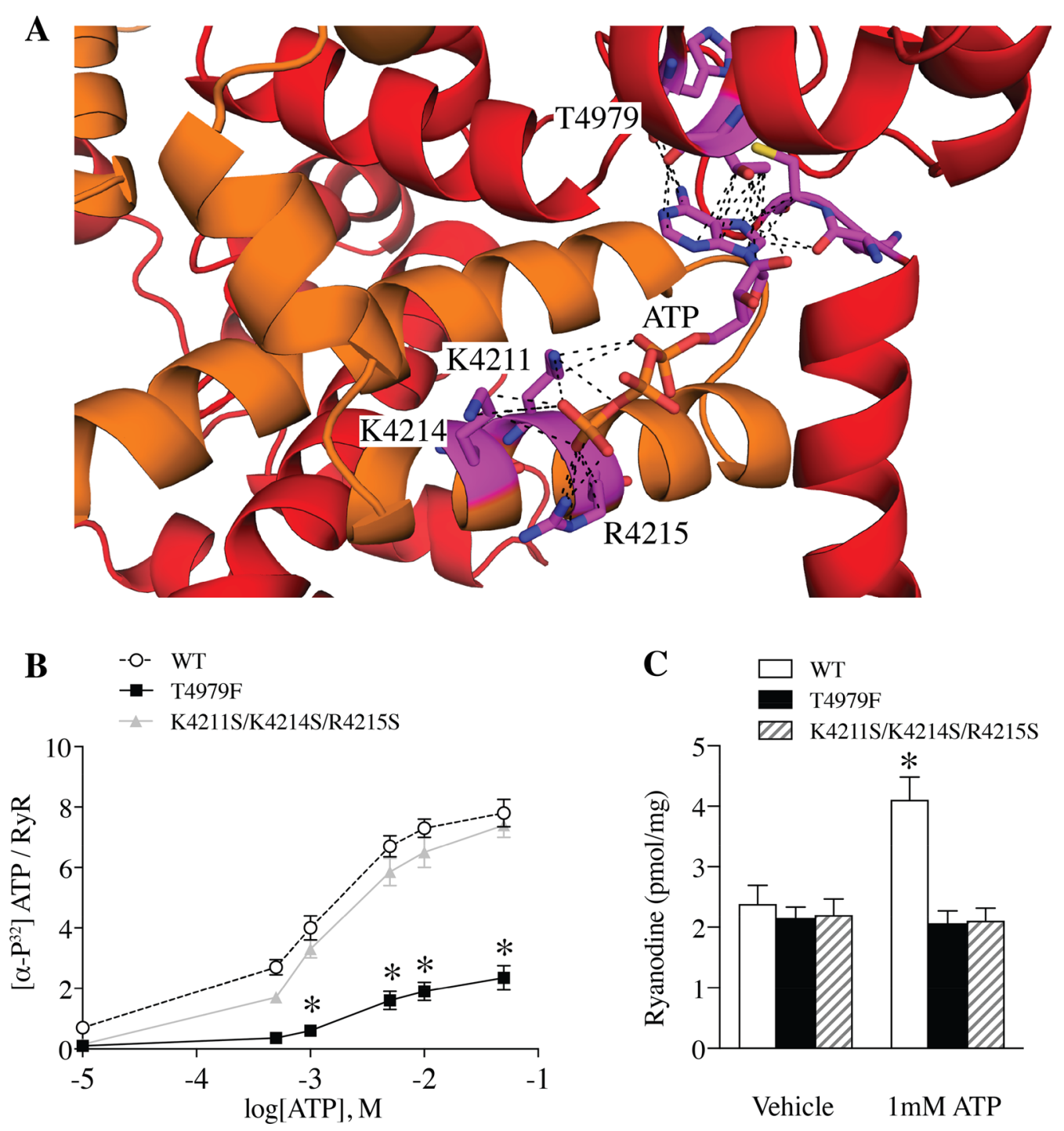

Fig. 2 Structure of the ATP binding site. A The adenine ring binding site (T4979) and triphosphate tail interacting residues (K4211, K4214, and R4215) are labeled and depicted in stick representation. $\mathbf{B}\left[\mathrm{a}-32^{\mathrm{P}}\right]-\mathrm{ATP} /\left[3^{\mathrm{H}}\right]$-ryanodine binding to ER microsomes of HEK293 cells expressing WT RyR1, T4979F, and K4211S/K4214S/R4215S. C, [ ${ }^{3} \mathrm{H}$-ryanodine binding to ER microsomes of HEK293 cells expressing WT RyR1 and ATP binding site mutants in response to ATP. Data are presented as the mean \pm S.E.M. $N=3$ for each group. ${ }^{* *} P<0.01$

indicator of channel activity. In the absence of ATP, the levels of $\left[{ }^{3} \mathrm{H}\right]$-ryanodine binding to T4979F RyR1 and K4211S/K4214S/R4215S RyR1 were similar to that of the WT RyR1 (Fig. 2C). In contrast, in the presence of $1 \mathrm{mM}$ ATP, WT RyR1 exhibited significantly increased $\left[{ }^{3} \mathrm{H}\right]$-ryanodine binding indicating channel activation, whereas T4979F and K4211S/K4214S/R4215S mutant channels did not (Fig. 2C). Thus, the ATP binding site identified by cryo-EM [14] is a functional site that regulates activity of RyR1.

Previously, we reported that in the presence of $30 \mu \mathrm{M}\left[\mathrm{Ca}^{2+}\right]_{c y t}$, the open probability of WT RyR1 channels was $\sim 20 \%$, while in the presence of $\mathrm{Ca}^{2+}$ / ATP/caffeine $(30 \mu \mathrm{M}, 1 \mathrm{mM}, 2 \mathrm{mM})$, the open probability was $\sim 90 \%$ [14]. This finding is consistent with many previous reports from multiple laboratories [47]. Single channel recordings were used as an additional assessment of the activation of RyR1 by ATP. WT RyR1 channels exhibited an open probability (Po) of $20 \%$, mean open time (To) of $2.1 \mathrm{~ms}$ and mean closed time (Tc) of $30.1 \mathrm{~ms}$ at $10 \mu \mathrm{M}\left[\mathrm{Ca}^{2+}\right]_{c y t}$. Mutant RyR1 channels T4979F and K4211S/K4214S/R4215S exhibited similar single channel properties compared to WT RyR1 under this condition, suggesting normal 
$\mathrm{Ca}^{2+}$ dependent activation. Addition of $1 \mathrm{mM}$ ATP dramatically increased WT RyR1 Po (Fig. 3A, B), with increased To and reduced Tc of single RyR1 channels (Fig. 3A, C, D). However, $1 \mathrm{mM}$ ATP had no effect on the Po of T4979F or K4211S/K4214S/R4215S mutant channels (Fig. 3A-D). These data further indicate that these mutations eliminate ATP-dependent activation of RyR1 and confirm the functional importance of the ATP binding site idenbtified using cryo-EM (Fig. 2C).

\section{Architecture and function of the $\mathrm{RyR} 1 \mathrm{Ca}^{2+}$ binding site} Comparison of difference maps calculated from RyR1 preparations with or without $30 \mu \mathrm{M} \mathrm{Ca}{ }^{2+}$ revealed a $\mathrm{Ca}^{2+}$ binding site located at the interface of the CTD

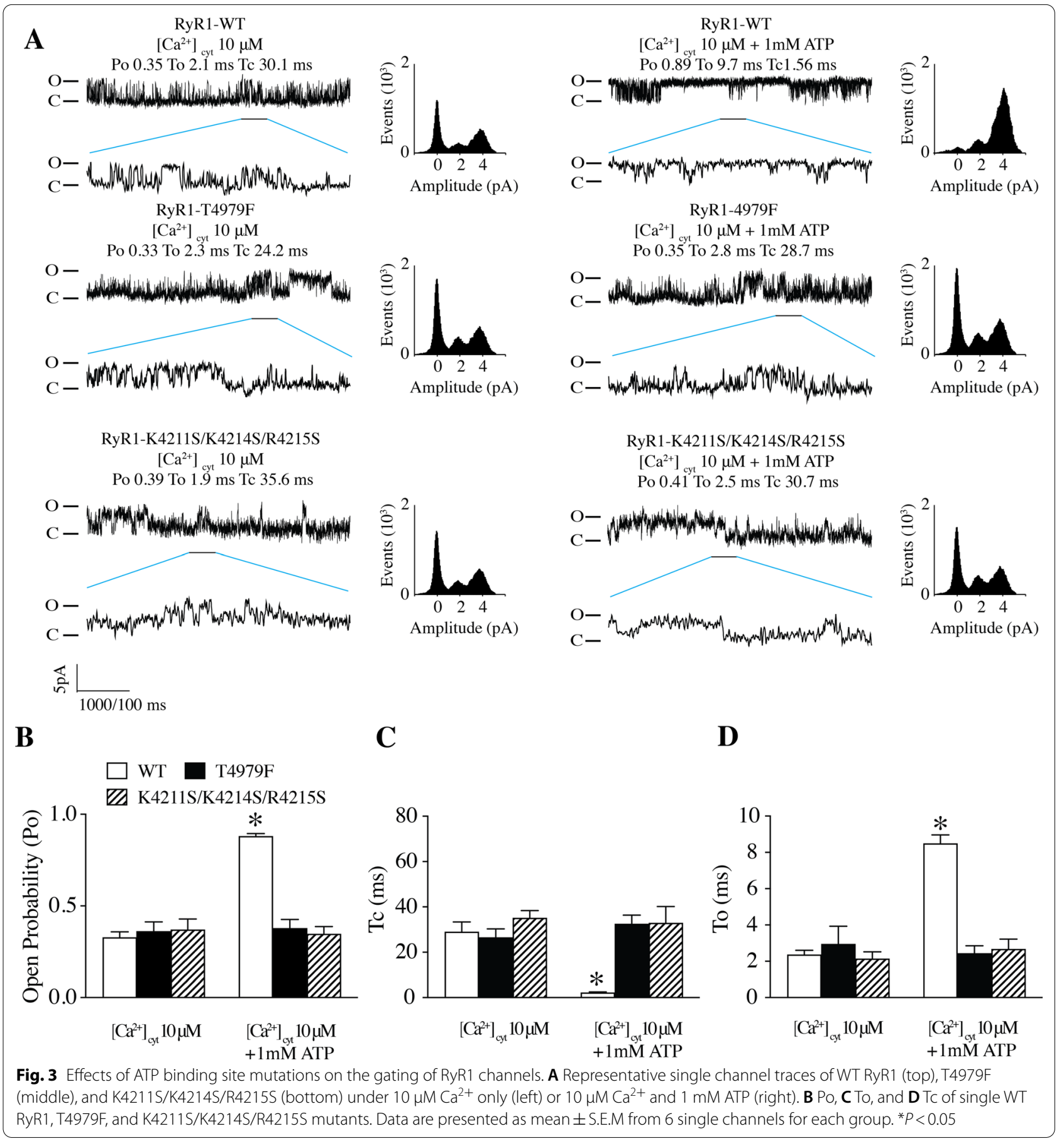


and the C-Sol [14]. This $\mathrm{Ca}^{2+}$ binding site is primarily comprised of five amino acids (Fig. 4A) which are conserved between RyR and the homologous inositol trisphosphate receptor (IP3R) channels [14, 21]. E3893 and E3967 from the C-Sol and T5001 from the CTD directly interact with $\mathrm{Ca}^{2+}$, and $\mathrm{H} 3895$ and Q3970 from the C-Sol indirectly interact with $\mathrm{Ca}^{2+}$ (Fig. 4A). In order to assess $\mathrm{Ca}^{2+}$-dependent ryanodine binding, we mutated E3893 and E3967 to either alanine or aspartic acid, expressed each mutant in HEK293 cells, and then determined $[3 \mathrm{H}]$-ryanodine binding to isolated ER vesicles. As shown in Fig. 4B, WT RyR1 exhibits a bell-shaped $\mathrm{Ca}^{2+}$ response with peak activation at $100 \mu \mathrm{M} \mathrm{Ca}^{2+}$. In contrast, E3893A, E3893D, E3967A, and E3967D mutant RyR1 channels exhibited both impaired activation at low $\left[\mathrm{Ca}^{2+}\right]$ and impaired deactivation at high $\left[\mathrm{Ca}^{2+}\right]$ (Fig. 4B).

To further assess the role of the $\mathrm{Ca}^{2+}$ binding site in RyR1 channel gating, we examined the single channel properties of the E3893A, E3893D, E3967A, and E3967D RyR1 channel mutants. WT and $\mathrm{Ca}^{2+}$-binding site mutants appropriately displayed low Po at $150 \mathrm{nM}$ cytosolic $\mathrm{Ca}^{2+}$ (Fig. 5); however, at $10 \mu \mathrm{M}\left[\mathrm{Ca}^{2+}\right]_{c y}$, WT RyR1 channels were activated (Fig. 5A), whereas E3893A, E3893D, E3967A, and E3967D mutant channels were not activated (Fig. 5B-F). Furthermore, $10 \mathrm{mM}$ cytosolic $\mathrm{Ca}^{2+}$ inhibited RyR1 WT channels, but the $\mathrm{Ca}^{2+}$-binding site mutants were not inhibited (Fig. 5B-F). Thus, the $\mathrm{Ca}^{2+}$-binding site mutants were insensitive to both $\mathrm{Ca}^{2+}$-dependent activation at $\left[\mathrm{Ca}^{2+}\right]_{c y t}$ below $100 \mu \mathrm{M}$, and $\mathrm{Ca}^{2+}$-dependent inhibition at $\left[\mathrm{Ca}^{2+}\right]_{c y t}$ above $1 \mathrm{mM}$ (Fig. 5B-F). Furthermore, these data suggest that a single $\mathrm{Ca}^{2+}$-binding site confers both the high and low affinity $\left[\mathrm{Ca}^{2+}\right]_{\text {cyt }}$ dependence of RyR1 channel activity.
RYR1-RD-associated mutations near ATP and $\mathrm{Ca}^{2+}$ binding sites

RYR1 mutations can cause skeletal muscle dysfunction in children and adults, resulting in a wide range of disabilities, and are the most common cause of congenital myopathy [27]. We have established an RYR1-RD database by assembling genetic, structural, biophysical, and clinical information from more than 2200 RYR1-RM affected patients [27]. This database contains an RyR1 mutation at T4980M (rabbit RyR1 T4979M) associated with congenital myopathy [23, 24, 37]. RyR1-T4980 is located in the ATP binding site where it may interact with the adenine ring of ATP (Fig. 2A). The patient in the database with this mutation also had a second mutation, A538T; however, this mutation is located in the NTD of RyR1, which is far from ligand binding sites and myopathy hotspots. To study the effects of these RyR1 myopathic mutations, T4979M, A538T and A538T/T4979M mutant channels were expressed in HEK293 cells. $1 \mathrm{mM}$ ATP did not increase the Po of RyR1 T4979M and A538T/T4979M mutant channels, whereas the mutant RyR1 A538T channel responded normally to ATP (Fig. 6A). A538T channels exhibited similar ATP-dependent activation as WT RyR1 channels (Fig. 6B). RyR1 T4979M and A538T/ T4979M mutant channels also displayed significantly decreased $\left[\alpha-{ }^{32} \mathrm{P}\right]$-ATP binding compared to WT RyR1 channels, while RyR1 A538T exhibited normal ATP binding (Fig. 6C), Taken together, these results show that mutation of threonine to methionine at 4980 of human RyR1 significantly attenuates ATP binding and activation of the RyR1 channel. Impaired ATP-dependent activation of RyR1 may contribute to muscle weakness in RYR1-RD affected patients.
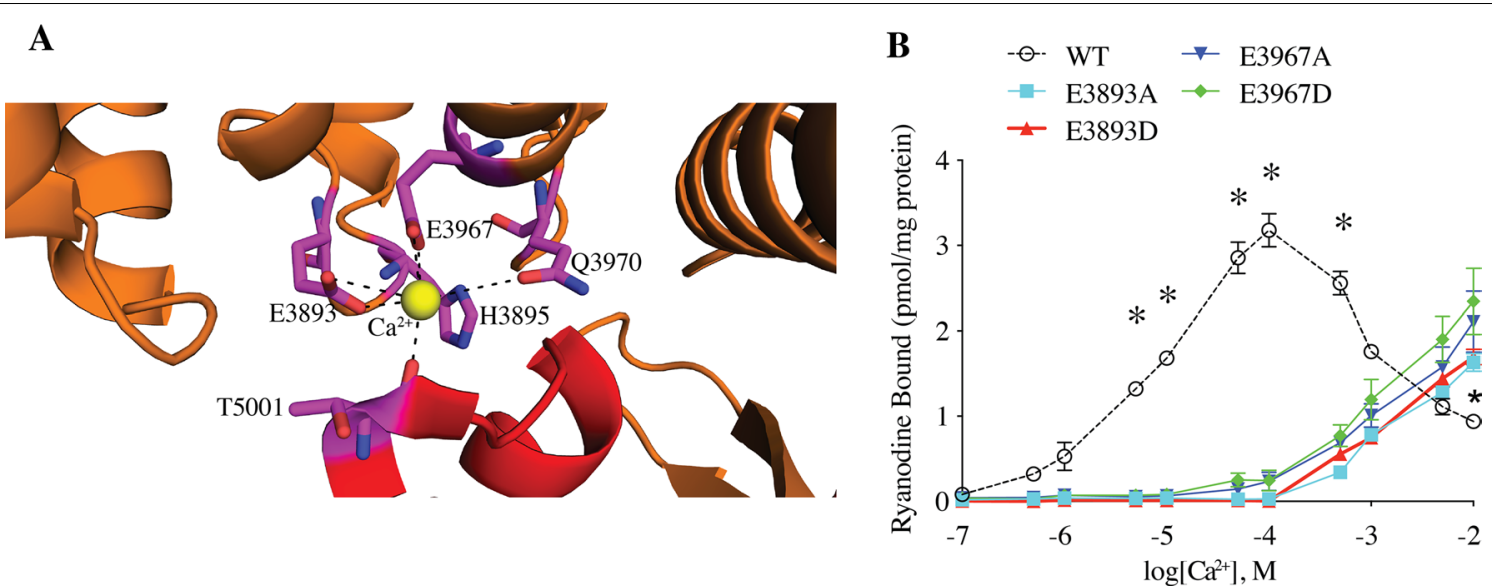

Fig. 4 Structure of the calcium binding site. $\mathbf{A}$ ribbon structure of the $\mathrm{Ca}^{2+}$ binding site showing interacting residues. $\mathbf{B}\left[^{3} \mathrm{H}\right]$-ryanodine binding to ER microsomes of HEK293 cells expressing WT RyR1 and calcium binding site mutants. Data are presented as mean \pm S.E.M from 6 single channels for each group. ${ }^{* *} P<0.01$ 
$\mathbf{A}$

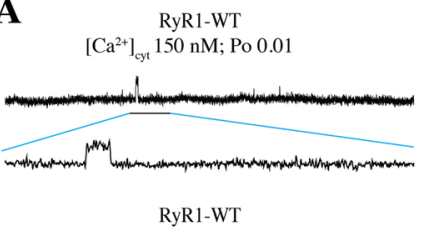

$\left[\mathrm{Ca}^{2+}\right]_{\text {cyt }} 10 \mu \mathrm{M} ;$ Po 0.51

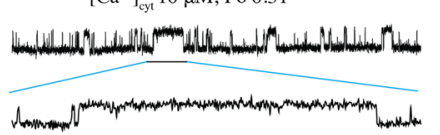

RyR1-WT

$\left[\mathrm{Ca}^{2+}\right]_{\text {cyt }} 10 \mathrm{mM}$; Po 0.02

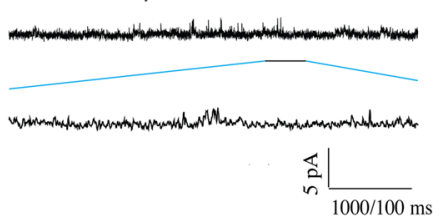

C

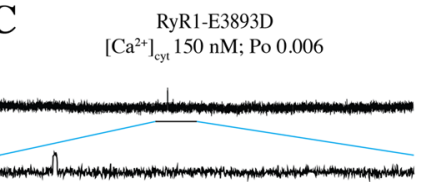

RyR1-E3893D

$\left[\mathrm{Ca}^{2+}\right]_{\text {cyt }} 10 \mu \mathrm{M} ;$ Po 0.03

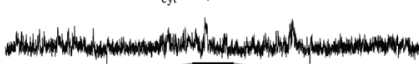

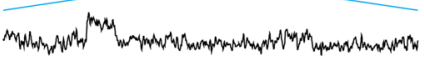

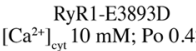

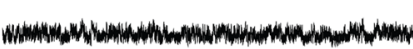

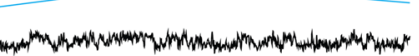
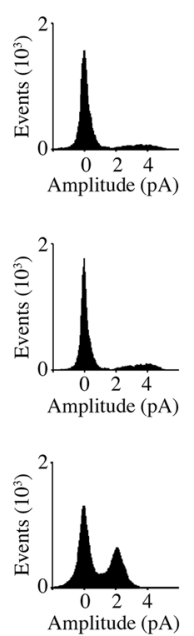

$\mathbf{E}$

RyR1-E3967D

$\left[\mathrm{Ca}^{2+}\right]_{\text {cyt }} 150 \mathrm{nM}$; Po 0.008

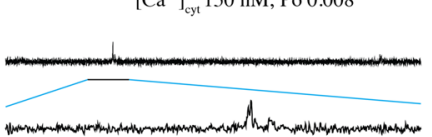

RyR1-E3967D

$\left[\mathrm{Ca}^{2+}\right]_{\mathrm{cyt}} 10 \mu \mathrm{M} ;$ Po 0.03

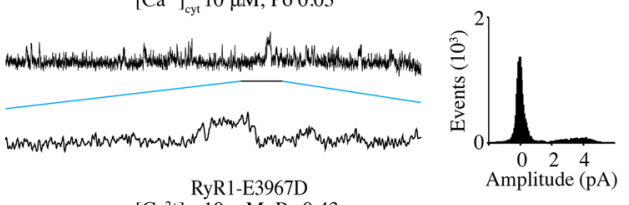

$\left[\mathrm{Ca}^{2+}\right]_{\mathrm{cyt}} 10 \mathrm{mM} ;$ Po 0.43
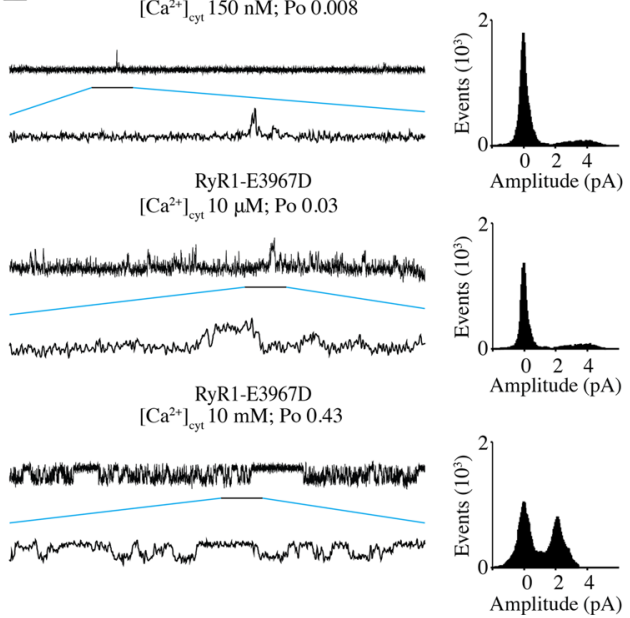

B

RyR1-E3893A

$\left[\mathrm{Ca}^{2+}\right]_{\text {cyt }} 150 \mathrm{nM}$; Po 0.007

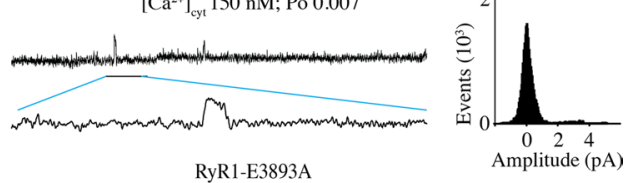

$\left[\mathrm{Ca}^{2+}\right]_{\mathrm{cyt}} 10 \mu \mathrm{M}$; Po 0.02

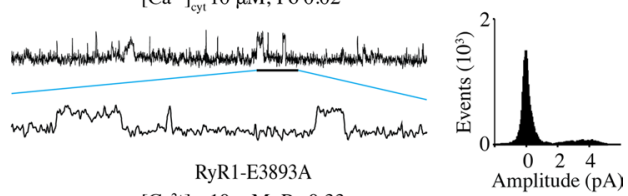

$\left[\mathrm{Ca}^{2+}\right]_{\text {cyt }} 10 \mathrm{mM}$; Po 0.33

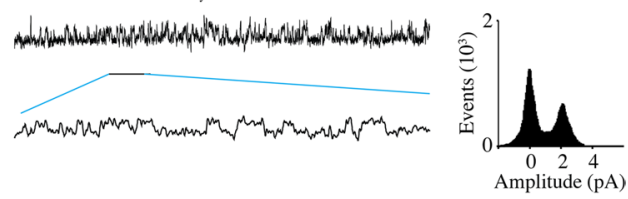

D

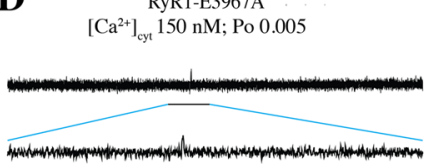

RyR1-E3967A

$\left[\mathrm{Ca}^{2+}\right]_{\text {cyt }} 10 \mu \mathrm{M}$; Po 0.04

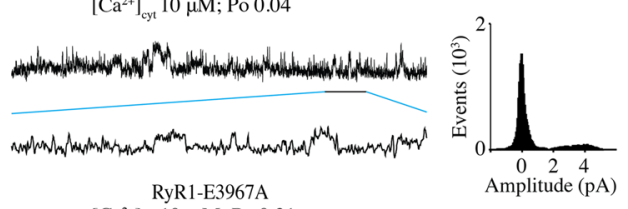

$\left[\mathrm{Ca}^{2+}\right]_{\mathrm{cyt}} 10 \mathrm{mM}$; Po 0.31

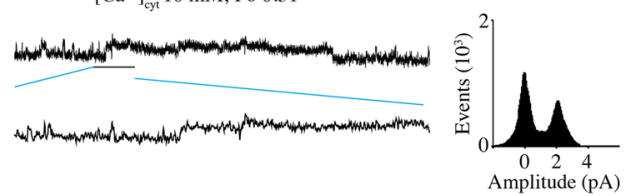

$\mathbf{F}$
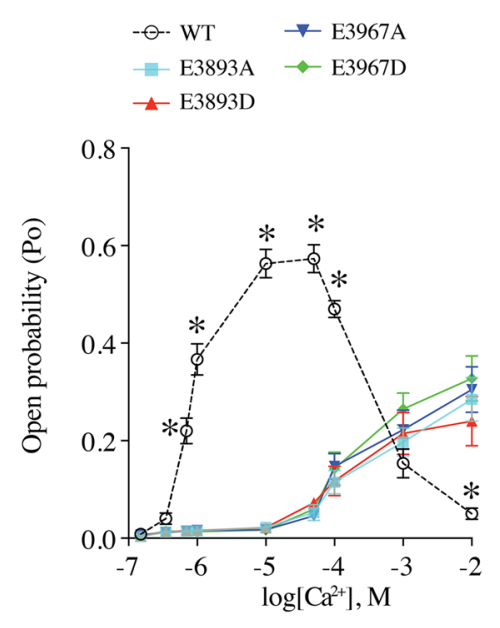

Fig. 5 Effects of mutations in the $\mathrm{Ca}^{2+}$ binding site on the gating of RyR1 channels. Representative single channel traces of WT RyR1 (A), E3893A (B), E3893D (C), E3967A (D), and E3967D (E), under $150 \mathrm{nM} \mathrm{Ca}^{2+}, 10 \mu \mathrm{M} \mathrm{Ca}^{2+}$, or $10 \mathrm{mM} \mathrm{Ca}{ }^{2+}$. F, Po versus Ca ${ }^{2+}$ concentration curve. Data are presented as mean \pm S.E.M from 6 single channels for each group 


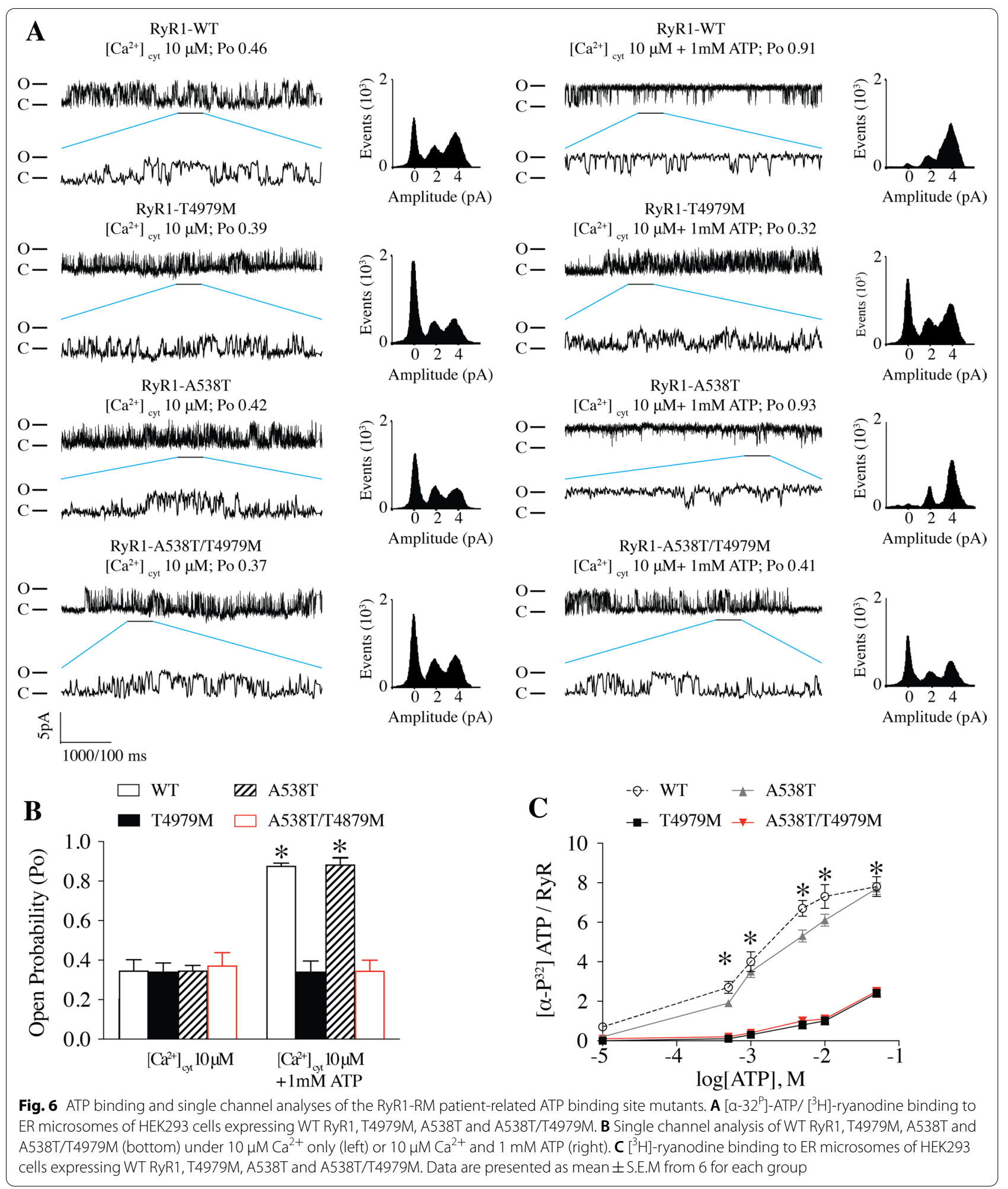

There are also RYR1-RD associated mutations near the $\mathrm{Ca}^{2+}$-binding site, including the human RyR1 mutation Q3969K (rabbit Q3970K) and S4028L. The
Q3970K mutation is linked to a form of RYR1-RD formerly referred to as multi-minicore disease [62]. Q3970K mutant channels displayed a right shift in $\mathrm{Ca}^{2+}$ 


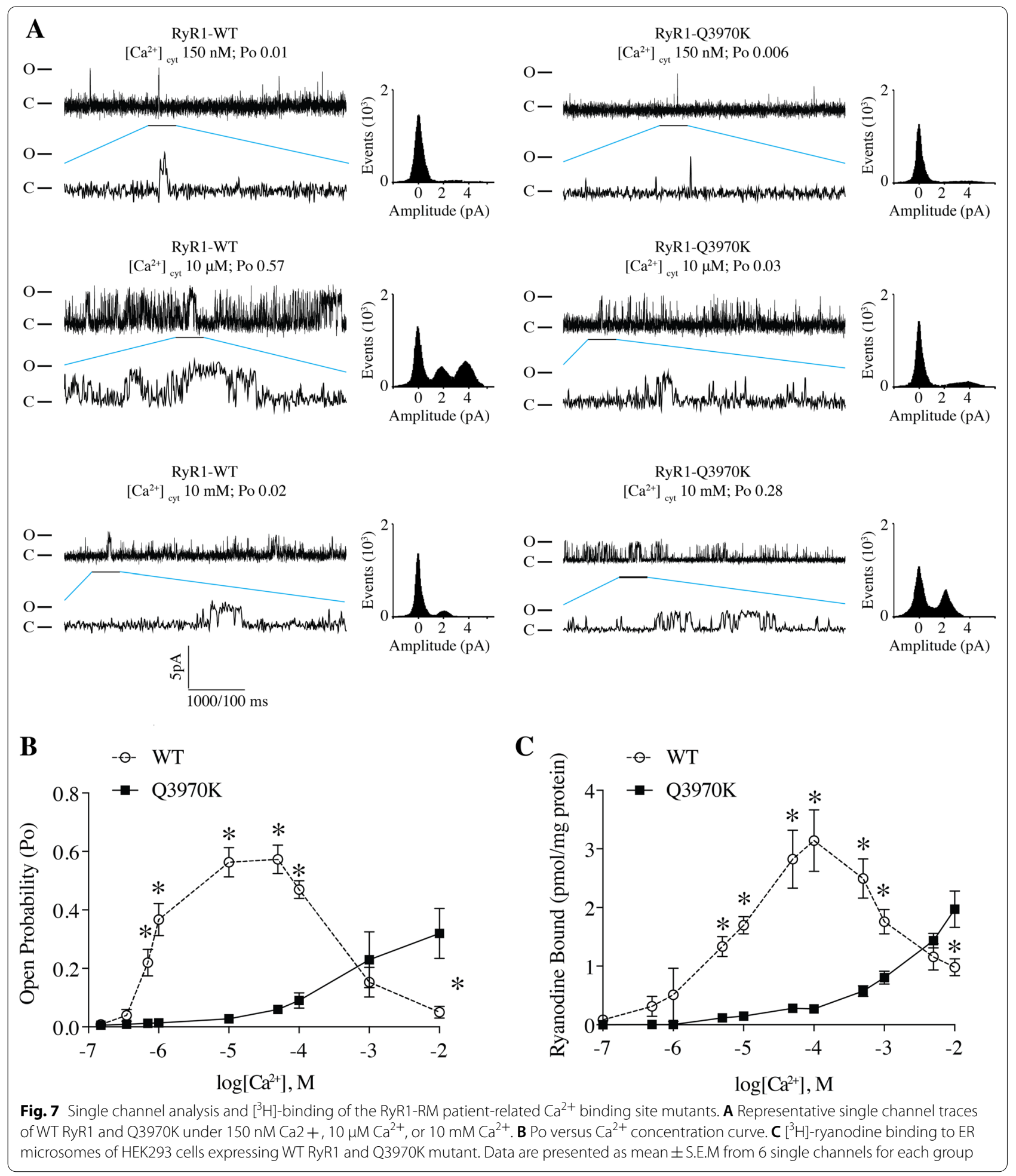

dependent activation measured using single channel determinations and $\left[{ }^{3} \mathrm{H}\right]$-ryanodine binding (Fig. 7AC). Our previous work regarding the S4028L mutation showed that the RyR1 channel from this patient's muscle biopsy exhibited elevated Po at low, non-activating $\left[\mathrm{Ca}^{2+}\right]_{c y t}$, consistent with a leaky RyR1 channel that likely plays a role in the patient's muscle weakness [27]. To assess the role of posttranslational modifications in 
determining the leaky behavior of disease-associated mutant RyR1 channels, RyR1-S4028L patient muscle lysates were treated with protein phosphatase 1 (PP1) and the reducing agent dithiothreitol (DTT), to reverse PKA phosphorylation and oxidation of the channel. Following this treatment, the mutant RyR1-RD linked RyR1S4028L channels still exhibited increased sensitivity to $\mathrm{Ca}^{2+}$-dependent activation and showed increased activity at very low non-activating $\left[\mathrm{Ca}^{2+}\right] \sim 150 \mathrm{nM}$, which is consistent with channel leak, albeit to a lesser extent than the phosphorylated and oxidized mutant channels (Additional file 1: Figure 1). These data indicate that the RyR1RD linked mutation alone increases the sensitivity of the channel to $\mathrm{Ca}^{2+}$-dependent activation rendering the channel leaky and that stress-induced posttranslational modifications further exacerbate the channel dysfunction and resultant leak.

\section{Discussion}

We previously solved the structure of RyR1 to nearatomic resolution using cryo-EM and identified ATP and $\mathrm{Ca}^{2+}$ binding sites $[14,76]$. In the present study, we have characterized the function of the ATP and $\mathrm{Ca}^{2+}$ binding sites of RyR1 using mutagenesis and measurements of channel activity. Importantly, the RYR1-RD linked mutation T4980M, which is located in the ATP binding site, impairs ATP binding and ATP-dependent activation of the RyR1 channel. The RyR1-RD linked mutation Q3969K, which is located in the $\mathrm{Ca}^{2+}$ binding site, abolishes $\mathrm{Ca}^{2+}$-dependent activation. These findings suggest that interference with $\mathrm{Ca}^{2+}$ - and ATP-dependent regulation of RyR1 may contribute to the pathophysiology of RyR1-RD including muscle weakness.

In skeletal muscle, the cytosolic ATP concentration is about $5 \mathrm{mM}$ [25], but under physiological conditions, ATP regulation of RyR 1 is influenced by $\mathrm{Mg}^{2+}$, a potent inhibitor of the RyR [13], and most cellular ATP is present as MgATP. Other nucleotides, such as CTP, GTP, ITP, and UTP, have no effect on RyR activity [46], which is consistent with our finding that the adenine base binding site is required for ATP binding to the RyR. We showed that T4979 is required for proper ATP-dependent regulation of RyR1 as RyR1-T4979F shows no binding with $\left[\alpha-{ }^{32} \mathrm{P}\right]$ ATP. It is possible that the introduction of phenylalanine with a bulky hydrophobic group in the binding site of the adenine of ATP (T4979F) prevents the entry of ATP into that site, thus explaining why ATP binding to the T4979F mutant RyR1 is reduced. Other adenine nucleotides such as ADP, AMP, or adenosine can also increase the Po of RyR1, but with reduced efficacy $[10,30]$ suggesting that the phosphate groups of ATP are required for robust activation of RyR1. Previous work has reported that the triphosphate groups are the most important element for inducing a long open state in RyR2 [35], in the present study we have extended these studies by presenting data identifiying the specific amino acid residues in RyR1 that are responsible for binding to the triphosphate tail of ATP in it's binding site. Indeed, in the present study, we demonstrate the structural basis for the critical role of the triphosphate tail of ATP in the activation of the RyR as the K4211S/K4214S/R4215S mutant RyR1, which replaces the positively charged lysine and arginine with a neutral serine, disrupts ATP-dependent activation of RyR1. The reduction in positively charged residues is presumed to decrease binding to the triphosphate tail of ATP in a way that mimics the reduced interaction of ADP and AMP with RyR1, both of which are much weaker activators of the channel $[10,30]$. Since ATP is always present at $\mathrm{mM}$ levels in muscle it is reasonable to hypothesize that its binding to RyR1 is required for robust activation of the channel by $\mathrm{Ca}^{2+}$. The mutant channels which cannot bind ATP are likely less active and may contribute to impaired muscle contractility and weakness in RYR1-RD patients.

Global cytosolic $\left[\mathrm{Ca}^{2+}\right]_{\text {cyt }}$ in resting cells is approximately $100-150 \mathrm{nM}$ and rises to at least $1 \mu \mathrm{M}$ following $\mathrm{Ca}^{2+}$ release through RyR1 during EC coupling. Mutations of RyR1 residues E3893 and E3967 to either A or D significantly reduced the high affinity $\mathrm{Ca}^{2+}$-dependent-activation of RyR1 compared to the WT channel (Fig. 4), which is consistent with previous work showing that mutation of those 2 Glutamic acid residues to Glutamine $(\mathrm{Q})$ or Valine $(\mathrm{V})$ interfered with $\mathrm{Ca}^{2+}$ regulation of the channel [72]. However, unexpectedly, these same mutations also prevented the low affinity $\mathrm{Ca}^{2+}$-dependent deactivation of RyR1. This finding suggests that the $\mathrm{Ca}^{2+}$-dependent activation and inhibition involves a single $\mathrm{Ca}^{2+}$ binding site. One possible mechanism to explain this phenomenon is that at low $\mathrm{Ca}^{2+}$ concentration (from $\mathrm{nM}$ to $\mu \mathrm{M}$ ), this $\mathrm{Ca}^{2+}$ binding site was occupied by one $\mathrm{Ca}^{2+}$, which forms a brige between the CTD and CSol to stabilize the open state of the RyR1 channel, whereas at high $\mathrm{Ca}^{2+}$ concentration $(\mathrm{mM})$, CTD and CSol each bind to one $\mathrm{Ca}^{2+}$, which disrupts the CTD-CSol interface to make the channel close. A patient with a Q3970K mutation at this site exhibited the same impaired $\mathrm{Ca}^{2+}$-dependent activation and deactivation as the E3893A/D and E3967A/D mutant channels, which is consistent with a previous study showing that RyR1Q3970K displayed low $\mathrm{Ca}^{2+}$ dependent channel activity [11]. It is likely that the additional positive charge from the lysine substitution in the Q3970K mutant channel reduces $\mathrm{Ca}^{2+}$-binding at this site. Similarly, the replacement of glutamic acid at 3967 or 3893 with the neutral alanine may reduce the affinity of the $\mathrm{Ca}^{2+}$ and thus impair both activation and deactivation, indicating the 
negative charges of glutamic acid are critical for the $\mathrm{Ca}^{2+}$ binding of RyR1. Replacing the glutamic acid at 3967 with an aspartic acid preserves the negative charge; however, since the side chain of glutamate is larger than that of aspartic acid, the interaction with $\mathrm{Ca}^{2+}$ may be weakened.

A previous study suggested that E4032 is part of the $\mathrm{Ca}^{2+}$ binding site of RyR1, as mutation of E4032 reduced $\mathrm{Ca}^{2+}$ activation in both RyR1 and RyR2 [20,34]. However, our cryo-EM RyR1 structure indicates that E4032 is not close enough to the $\mathrm{Ca}^{2+}$ binding site to form a direct interaction with the bound $\mathrm{Ca}^{2+}$. Nevertheless, it may stabilize the CTD-CSol interface via hydrogen bonding to the amide nitrogens at the end of one of the CTD helices [14]. Interestingly, a mutant channel RyR1-S4028L which has been linked to RYR1-RM [27], exhibited increased $\mathrm{Ca}^{2+}$-dependent activation of RyR1 at low non-activating $\left[\mathrm{Ca}^{2+}\right]_{c y \text {, }}$, which is consistent with channel leak [27], suggesting that the polar side chain of serine is necessary to stabilize the CTD-CSol interface. Moreover, blocking or reversing post-translational modifications of RyR1 (PKA phosphorylation and oxidation) revealed that the channel mutation alone is sufficient to cause $\mathrm{Ca}^{2+}$ leak and that the posttranslational modications are additive in terms of leak.

The present study identifies functional ATP and $\mathrm{Ca}^{2+}$-dependent regulatory sites in RyR1. Moreover, these are also the sites of RyR1-RM disease causing mutations, indicating that defective regulation of RyR1 by $\mathrm{Ca}^{2+}$ and ATP may be a component of the pathophysiology of this form of myopathy.

\section{Materials and methods}

\section{Ryanodine receptor mutagenesis and expression}

The recombinant RyR1 constructs T4979F, K4211S/ K4214S/R4215S, E3893A, E3893D, E3967A, E3967D, $\mathrm{T} 4979 \mathrm{M}$, and Q3970K were generated by introducing the respective mutations into fragments of rabbit RyR1 using QuikChange II XL Site-Directed Mutagenesis Kit (Agilent). Each fragment was subsequently subcloned into a full length RyR1 construct in pcDNA3.1 vector and confirmed by sequencing. The primers used to introduce specific mutants (codons in parentheses, mutated nucleotides in bold) are as follows: $5^{\prime}$-cacggcttcgagacccac(ttc)ctagaggagcacaatctg for T4979F, $5^{\prime}$-gtgggagatgccccaggtc $($ agc $)$ gagtcc $($ agc $)($ agc $)$ cagttcatcttc for K4211S-K4214S-R4215S, 5'-gcagctgctctgt(gcg) gggcacaacaacg for E3893A, 5'-ctgcagctgctctgt(gac) gggcacaac for E3893D, 5'-caacagctcacc(gcg)tacatccagggcc for E3967A, 5'-acagcctcacc(gac)tacatccagggcc for E3967D, 5'-cacggcttcgagacccac(atg)ctagaggag for T4979M, and 5'-ctcaccgagtacatc(aag)ggccctgcac for Q3970K. For all mutants, the second primer was the complementary reverse to the forward primer. HEK293 cells grown in DMEM supplemented with $10 \%$ (vol/vol) FBS (Invitrogen), penicillin $(100 \mathrm{U} / \mathrm{mL})$, streptomycin $(100 \mu \mathrm{g} / \mathrm{mL})$, and L-glutamine $(2 \mathrm{mmol} / \mathrm{L})$ were transfected with WT or mutant RyR1 cDNA using Lipofectamine 2000 (ThermoFisher Scientific). Cells were collected $48 \mathrm{~h}$ after transfection.

\section{ER vesicles preparation}

ER vesicles from HEK293 cells expressing WT or mutant RyR1 were prepared by homogenizing cell pellets on ice using a Teflon-glass homogenizer with two volumes of solution containing $20 \mathrm{mmol} / \mathrm{L}(\mathrm{mM})$ Tris-maleate $(\mathrm{pH}$ 7.4), $1 \mathrm{mM}$ EDTA, $1 \mathrm{mM}$ DL-Dithiothreitol (DTT) and protease inhibitors (Roche). Homogenate was then centrifuged at $4,000 \mathrm{xg}$ for $15 \mathrm{~min}$ at $4{ }^{\circ} \mathrm{C}$ and the resulting supernatant was centrifuged at 40,000 $\mathrm{xg}$ for $30 \mathrm{~min}$ at $4{ }^{\circ} \mathrm{C}$. The final pellet, containing the ER fractions, was resuspended and aliquoted in $250 \mathrm{mM}$ sucrose, $10 \mathrm{mM}$ MOPS (pH 7.4), 1 mM EDTA, 1 mM DTT and protease inhibitors. Samples were frozen in liquid nitrogen and stored at $-80^{\circ} \mathrm{C}$.

\section{SR microsome preparation}

Skeletal muscle SR microsomes were prepared as previsouly described [27]. Briefly, muscle samples were homogenized on ice using a Teflon-glass homogenizer with 2 volumes of: $20 \mathrm{mmol} / \mathrm{L}(\mathrm{mM})$ Tris-maleate $(\mathrm{pH}$ 7.4), $1 \mathrm{mM}$ EDTA, $1 \mathrm{mM}$ DL-dithiothreitol (DTT) and protease inhibitors (Roche). The resulting homogenate was then centrifuged at $4,000 \mathrm{~g}$ for $15 \mathrm{~min}$ at $4{ }^{\circ} \mathrm{C}$ and the supernatant was centrifuged at 50,000 $\mathrm{g}$ for $45 \mathrm{~min}$ at $4{ }^{\circ} \mathrm{C}$. Pellets were resuspended in lysis buffer containing $300 \mathrm{mM}$ sucrose.

\section{$\left[{ }^{3} \mathrm{H}\right]$ Ryanodine and $\left[\mathrm{a}^{32} \mathrm{P}\right]-\mathrm{ATP}$ binding}

Skeletal muscle SR microsomes or ER vesicles from HEK293 cells expressing WT or mutant RyR1 were incubated in media containing $5 \mathrm{nM}\left[{ }^{3} \mathrm{H}\right]$-ryanodine or $5 \mathrm{nM}$ $\left[\alpha{ }^{32} \mathrm{P}\right]$-ATP, $1 \mathrm{M} \mathrm{NaCl}, 20 \mathrm{mM}$ HEPES, and $0.5 \mathrm{mM}$ EGTA at $37{ }^{\circ} \mathrm{C}$ for $2 \mathrm{~h}$. The concentration of free $\mathrm{Ca}^{2+}$ was calculated with WinMaxC (version 2.50; www.stanf ord.edu/ cpatton/maxc.html). For ATP activation, $1 \mathrm{mM}$ ATP and $1 \mathrm{mM}$ free $\mathrm{Ca}^{2+}$ were added during incubation. The binding mix was then filtered through Whatman GF/B filters presoaked with $1 \%$ polyethyleneimine. The filters were washed three times with $5 \mathrm{~mL}$ of ice-cold washing buffer containing $0.2 \mathrm{M} \mathrm{NaCl}$ and $5 \mathrm{mM}$ HEPES $\left(\mathrm{pH}\right.$ 7.5) to remove unbound $\left[{ }^{3} \mathrm{H}\right]$-ryanodine, and the amount of remaining $\left[{ }^{3} \mathrm{H}\right]$-ryanodine was determined by liquid scintillation counting. Nonspecific binding was determined by measuring $\left[{ }^{3} \mathrm{H}\right]$-ryanodine binding in 
the presence of $10 \mu \mathrm{M}$ unlabeled ryanodine. All binding assays were done in duplicate.

\section{Single-channel recordings}

ER vesicles were fused to planar lipid bilayers formed by painting a lipid mixture of phosphatidylethanolamine and phosphatidylcholine (Avanti Polar Lipids) in a 5:3 ratio in decane across a $200 \mu \mathrm{m}$ hole in polysulfonate cups (Warner Instruments) separating two chambers. The trans chamber $(1.0 \mathrm{~mL})$, representing the intra-SR (luminal) compartment, was connected to the head stage input of a bilayer voltage clamp amplifier. The cis chamber $(1.0 \mathrm{~mL})$, representing the cytoplasmic compartment, was held at virtual ground. Asymmetrical solutions used were as follows for the cis solution: $1 \mathrm{mM}$ EGTA, 250/125 mM Hepes/Tris, $50 \mathrm{mM} \mathrm{KCl,} 0.64 \mathrm{mM} \mathrm{CaCl}_{2}$, $\mathrm{pH}$ 7.35; and for the trans solution: $53 \mathrm{mM} \mathrm{Ca}(\mathrm{OH})_{2}$, $50 \mathrm{mM} \mathrm{KCl}, 250 \mathrm{mM}$ Hepes, $\mathrm{pH}$ 7.35. The concentration of free $\mathrm{Ca}^{2+}$ in the cis chamber was calculated as previously described [14]. ER vesicles were added to the cis side and fusion with the lipid bilayer was induced by making the cis side hyperosmotic by the addition of 400$500 \mathrm{mM} \mathrm{KCl}$. After the appearance of potassium and chloride channels, the cis side was perfused with the $c$ is solution. At the end of each experiment, $10 \mu \mathrm{M}$ ryanodine was added to block the RyR channel. Single-channel currents were recorded at $0 \mathrm{mV}$ using a Bilayer Clamp BC-525D (Warner Instruments), filtered at $1 \mathrm{kHz}$ using a Low-Pass Bessel Filter 8 Pole (Warner Instruments), and digitized at $4 \mathrm{kHz}$. All experiments were performed at room temperature $\left(23^{\circ} \mathrm{C}\right)$. Data acquisition was performed by using Digidata 1322A and Axoscope 10.1 software (Axon Instruments). The recordings were analyzed using Clampfit 10.1 (Molecular Devices) and Graphpad Prism software.

\section{Immunoprecipitation and immunoblotting}

RyR1 were immunoprecipitated from extracts of human patient muscle biopsy using anti- anti-RyR1-specific antibodies $(2 \mu \mathrm{g})$ in $0.5 \mathrm{ml}$ of a modified radioimmune precipitation assay buffer $(50 \mathrm{~mm}$ Tris- $\mathrm{HCl}, \mathrm{pH} 7.2,0.9 \%$ $\mathrm{NaCl}, 5.0 \mathrm{~mm} \mathrm{NaF}, 1.0 \mathrm{~mm} \mathrm{Na} \mathrm{VO}_{4}, 1 \%$ Triton X-100 and protease inhibitors) overnight at $4{ }^{\circ} \mathrm{C}$ as previously described [2]. The immune complexes were incubated with protein A-Sepharose beads (Sigma-Aldrich) at $4{ }^{\circ} \mathrm{C}$ for $1 \mathrm{~h}$ and the beads were washed three times with the modified radioimmune precipitation assay buffer. The immunoprecipitated proteins were size-fractionated on SDS-polyacrylamide gels (4-20\% for RyR1) and transferred to nitrocellulose membranes for $2 \mathrm{~h}$ at a current of $200 \mathrm{~mA}$. Immunoblots were probed with the following primary antibodies: anti-RyR1 (Affinity Bioreagents, 1:2,000 dilution), anti-Cys-NO (Sigma-Aldrich, 1:1,000 dilution), or anti-phospho-RyR-Ser(P)-2844 (Affinity Bioreagents, 1:5,000 dilution). To determine channel oxidation, the carbonyl groups in the protein side chains were derivatized to 2,4-dinitrophenol (DNP) by reaction with 2,4-dinitrophenylhydrazine. The DNP signal associated with total oxidized protein or with RyR was determined using a specific anti-DNP antibody according to the manufacturer's instructions (Millipore). All immunoblots were developed using an Odyssey system (LI-COR Biosciences), with infrared-labeled anti-mouse or anti-rabbit IgG (Abcam, 1:10,000 dilution) secondary antibodies.

\section{Statistics}

All results are presented as the mean \pm SEM. Statistical analyses were performed using the unpaired Student's $t$ test, 2-tailed (for 2 groups), or the 1-way ANOVA with Tukey-Kramer post hoc correction (for groups of 3 or more) unless otherwise indicated. $\mathrm{P}<0.05$ was considered to be statistically significant.

\section{Supplementary Information}

The online version contains supplementary material available at https://doi. org/10.1186/s40478-021-01287-3.

Additional file 1: Figure 1. RyR1-S4028L patient mutation causes RyR1 channel leak. (A) The mutant RyR1-S4028L channel was PKA phosphorylated at Ser2844 and oxidized (DNP) compared to control. PP1 and DTT were used to reverse the oxidation and phosphorylation. (B) The mutant RyR1-S4028L channels exhibited increased sensitivity to $\mathrm{Ca}^{2+}$-dependent activation consistent with channel leak as determined by ${ }^{3}[\mathrm{H}]$-ryanodine binding at the indicated $\left[\mathrm{Ca}^{2+}\right]_{c y t}$. Data are presented as mean \pm S.E.M from 4 for each group ${ }^{*} P<0.05$ vs. WT; ${ }^{\#} P<0.05$ vs. RyR1-S4028L, ANOVA, Tukey-Kramer with post hoc correction.

\section{Acknowledgements}

This study was is supported by R01HL145473, R01DK118240, R01HL142903, R01HL140934, R01AR070194, T32HL120826, and R25 NS076445 to ARM.

\section{Availability of data and materials}

The data supporting the findings of this are documented within the paper and are available from the corresponding author upon request.

\section{Declarations}

Competing interests

ARM is on the scientific advisory board, board of directors and is an equity owner in ARMGO, Inc. a biotech company targeting RyR for therapeutic purposes, Columbia University also owns equity in ARMGO, Inc.

\section{Author details}

${ }^{1}$ Department of Physiology and Cellular Biophysics, Vagelos College of Physicians and Surgeons of Columbia University, New York, NY 10032, USA.

${ }^{2}$ Department of Anesthesiology, Vagelos College of Physicians and Surgeons of Columbia University, New York, NY 10032, USA. ${ }^{3}$ Wu Center for Molecular Cardiology, Vagelos College of Physicians and Surgeons of Columbia University, Russ Berrie Medical Science Pavilion, 1150 St. Nicholas Avenue, New York, NY 10032, USA. ${ }^{4}$ Ilse Katz Institute for Nanoscale Science and Technology, Ben Gurion University of the Negev, Beersheba, Israel. 
Received: 26 October 2021 Accepted: 31 October 2021

Published online: 22 November 2021

\section{References}

1. Amburgey K, McNamara N, Bennett LR, McCormick ME, Acsadi G, Dowling JJ (2011) Prevalence of congenital myopathies in a representative pediatric united states population. Ann Neurol 70:662-665. https://doi. org/10.1002/ana.22510

2. Andersson DC, Betzenhauser MJ, Reiken S, Meli AC, Umanskaya A, Xie W, Shiomi T, Zalk R, Lacampagne A, Marks AR (2011) Ryanodine receptor oxidation causes intracellular calcium leak and muscle weakness in aging Cell Metab 14:196-207. https://doi.org/10.1016/j.cmet.2011.05.014

3. Andersson DC, Meli AC, Reiken S, Betzenhauser MJ, Umanskaya A, Shiomi T, D’Armiento J, Marks AR (2012) Leaky ryanodine receptors in beta-sarcoglycan deficient mice: a potential common defect in muscular dystrophy. Skelet Muscle 2:9. https://doi.org/10.1186/2044-5040-2-9

4. Beard NA, Dulhunty AF (2015) C-terminal residues of skeletal muscle calsequestrin are essential for calcium binding and for skeletal ryanodine receptor inhibition. Skelet Muscle 5:6. https://doi.org/10.1186/ s13395-015-0029-7

5. Bellinger AM, Reiken S, Carlson C, Mongillo M, Liu X, Rothman L, Matecki S, Lacampagne A, Marks AR (2009) Hypernitrosylated ryanodine receptor calcium release channels are leaky in dystrophic muscle. Nat Med 15:325-330. https://doi.org/10.1038/nm.1916

6. Berridge MJ, Bootman MD, Roderick HL (2003) Calcium signalling: dynamics, homeostasis and remodelling. Nat Rev Mol Cell Biol 4:517-529. https://doi.org/10.1038/nrm1155

7. Bezprozvanny I, Watras J, Ehrlich BE (1991) Bell-shaped calcium-response curves of Ins $(1,4,5) P 3$ - and calcium-gated channels from endoplasmic reticulum of cerebellum. Nature 351:751-754. https://doi.org/10.1038/ 351751a0

8. Blayney L, Beck K, MacDonald E, D'cruz L, Nomikos M, Griffiths J, Thanassoulas A, Nounesis G, Lai FA (2013) ATP interacts with the CPVT mutationassociated central domain of the cardiac ryanodine receptor. Biochim Biophys Acta 1830:4426-4432. https://doi.org/10.1016/j.bbagen.2013.05. 038

9. Bussiere R, Lacampagne A, Reiken S, Liu X, Scheuerman V, Zalk R, Martin C, Checler F, Marks AR, Chami M (2017) Amyloid beta production is regulated by beta2-adrenergic signaling-mediated post-translational modifications of the ryanodine receptor. J Biol Chem 292:10153-10168. https://doi.org/10.1074/jbc.M116.743070

10. Chan WM, Welch W, Sitsapesan R (2000) Structural factors that determine the ability of adenosine and related compounds to activate the cardiac ryanodine receptor. Br J Pharmacol 130:1618-1626. https://doi.org/10. 1038/sj.bjp.0703459

11. Chirasani VR, Xu L, Addis HG, Pasek DA, Dokholyan NV, Meissner G, Yamaguchi N (2019) A central core disease mutation in the $\mathrm{Ca}(2+)$-binding site of skeletal muscle ryanodine receptor impairs single-channel regulation. Am J Physiol Cell Physiol 317:C358-C365. https://doi.org/10.1152/ajpcell. 00052.2019

12. Clarke OB, Hendrickson WA (2016) Structures of the colossal RyR1 calcium release channel. Curr Opin Struct Biol 39:144-152. https://doi.org/10. 1016/j.sbi.2016.09.002

13. Copello JA, Barg S, Sonnleitner A, Porta M, Diaz-Sylvester P, Fill M, Schindler H, Fleischer S (2014) Differential activation by Ca2+, ATP and Caffeine of cardiac and skeletal muscle ryanodine receptors after block by Mg2+. J Membr Biol 187:51-64. https://doi.org/10.1007/s00232-001-0150-x

14. Desgeorges A, Clarke OB, Zalk R, Yuan Q, Condon KJ, Grassucci RA, Hendrickson WA, Marks AR, Frank J (2016) Structural basis for gating and activation of RyR1. Cell 167:145-157 e117. https://doi.org/10.1016/j.cell. 2016.08.075

15. DeSouza N, Reiken S, Ondrias K, Yang YM, Matkovich S, Marks AR (2002) Protein kinase A and two phosphatases are components of the inositol 1,4,5-trisphosphate receptor macromolecular signaling complex. J Biol Chem 277:39397-39400. https://doi.org/10.1074/jbc.M207059200

16. Dridi H, Liu X, Yuan Q, Reiken S, Yehia M, Sittenfeld L, Apostolou P, Buron J, Sicard P, Matecki S et al (2020) Role of defective calcium regulation in cardiorespiratory dysfunction in Huntington's disease. JCI Insight. https:// doi.org/10.1172/jci.insight.140614
17. Dulhunty AF, Laver D, Curtis SM, Pace S, Haarmann C, Gallant EM (2001) Characteristics of irreversible ATP activation suggest that native skeletal ryanodine receptors can be phosphorylated via an endogenous CaMKII. Biophys J 81:3240-3252. https://doi.org/10.1016/S0006-3495(01)75959-0

18. Efremov RG, Leitner A, Aebersold R, Raunser S (2015) Architecture and conformational switch mechanism of the ryanodine receptor. Nature 517:39-43. https://doi.org/10.1038/nature13916

19. Farrell EF, Antaramian A, Benkusky N, Zhu X, Rueda A, Gomez AM, Valdivia $\mathrm{HH}$ (2004) Regulation of cardiac excitation-contraction coupling by sorcin, a novel modulator of ryanodine receptors. Biol Res 37:609-612

20. Fessenden JD, Chen L, Wang Y, Paolini C, Franzini-Armstrong C, Allen PD, Pessah IN (2001) Ryanodine receptor point mutant E4032A reveals an allosteric interaction with ryanodine. Proc Natl Acad Sci USA 98:28652870. https://doi.org/10.1073/pnas.041608898

21. Harnick DJ, Jayaraman T, Ma Y, Mulieri P, Go LO, Marks AR (1995) The human type 1 inositol 1,4,5-trisphosphate receptor from T lymphocytes. Structure, localization, and tyrosine phosphorylation. J Biol Chem 270:2833-2840

22. Huang F, Shan J, Reiken S, Wehrens XH, Marks AR (2006) Analysis of calstabin2 (FKBP12.6)-ryanodine receptor interactions: rescue of heart failure by calstabin2 in mice. Proc Natl Acad Sci USA 103:3456-3461

23. Klein $A$, Jungbluth $H$, Clement $E$, Lillis $S$, Abbs $S$, Munot $P$, Pane $M$, Wraige E, Schara U, Straub V et al (2011) Muscle magnetic resonance imaging in congenital myopathies due to ryanodine receptor type 1 gene mutations. Arch Neurol 68:1171-1179. https://doi.org/10.1001/archneurol. 2011.188

24. Klein A, Lillis S, Munteanu I, Scoto M, Zhou H, Quinlivan R, Straub V, Manzur AY, Roper H, Jeannet PY et al (2012) Clinical and genetic findings in a large cohort of patients with ryanodine receptor 1 gene-associated myopathies. Hum Mutat 33:981-988. https://doi.org/10.1002/humu. 22056

25. Kushmerick MJ, Moerland TS, Wiseman RW (1992) Mammalian skeletal muscle fibers distinguished by contents of phosphocreatine, ATP, and Pi. Proc Natl Acad Sci USA 89:7521-7525

26. Kushnir A, Shan J, Betzenhauser MJ, Reiken S, Marks AR (2010) Role of CaMKIldelta phosphorylation of the cardiac ryanodine receptor in the force frequency relationship and heart failure. Proc Natl Acad Sci USA 107:10274-10279. https://doi.org/10.1073/pnas.1005843107

27. Kushnir A, Todd JJ, Witherspoon JW, Yuan Q, Reiken S, Lin H, Munce RH, Wajsberg B, Melville Z, Clarke OB et al (2020) Intracellular calcium leak as a therapeutic target for RYR1-related myopathies. Acta Neuropathol 139:1089-1104. https://doi.org/10.1007/s00401-020-02150-w

28. Lacampagne A, Liu X, Reiken S, Bussiere R, Meli AC, Lauritzen I, Teich AF, Zalk R, Saint N, Arancio O et al (2017) Post-translational remodeling of ryanodine receptor induces calcium leak leading to Alzheimer's diseaselike pathologies and cognitive deficits. Acta Neuropathol: https://doi.org/ 10.1007/s00401-017-1733-7

29. Lau K, Van Petegem F (2014) Crystal structures of wild type and disease mutant forms of the ryanodine receptor SPRY2 domain. Nat Commun 5:1-11. https://doi.org/10.1038/ncomms6397

30. Laver DR, Lenz GK, Lamb GD (2001) Regulation of the calcium release channel from rabbit skeletal muscle by the nucleotides ATP, AMP, IMP and adenosine. J Physiol 537:763-778. https://doi.org/10.1111/j.1469-7793. 2001.00763.x

31. Lawal TA, Todd JJ, Witherspoon JW, Bonnemann CG, Dowling JJ, Hamilton SL, Meilleur KG, Dirksen RT (2020) Ryanodine receptor 1-related disorders: an historical perspective and proposal for a unified nomenclature. Skelet Muscle 10:32. https://doi.org/10.1186/s13395-020-00243-4

32. Lehnart SE, Wehrens $X H$, Reiken $S$, Warrier S, Belevych AE, Harvey RD, Richter W, Jin SL, Conti M, Marks AR (2005) Phosphodiesterase 4D deficiency in the ryanodine-receptor complex promotes heart failure and arrhythmias. Cell 123:25-35

33. Li L, Mirza S, Richardson SJ, Gallant EM, Thekkedam C, Pace SM, Zorzato F, Liu D, Beard NA, Dulhunty AF (2015) A new cytoplasmic interaction between junctin and ryanodine receptor $\mathrm{Ca} 2+$ release channels. J Cell Sci 128:951-963. https://doi.org/10.1242/jcs.160689

34. Li P, Chen SR (2001) Molecular basis of $\mathrm{Ca}(2)+$ activation of the mouse cardiac $\mathrm{Ca}(2)+$ release channel (ryanodine receptor). J Gen Physiol 118:33-44. https://doi.org/10.1085/jgp.118.1.33

35. Lindsay C, Sitsapesan M, Chan WM, Venturi E, Welch W, Musgaard M, Sitsapesan R (2018) Promiscuous attraction of ligands within the ATP binding 
site of RyR2 promotes diverse gating behaviour. Sci Rep 8:15011. https:// doi.org/10.1038/s41598-018-33328-8

36. Liu X, Betzenhauser MJ, Reiken S, Meli AC, Xie W, Chen BX, Arancio O, Marks AR (2012) Role of leaky neuronal ryanodine receptors in stressinduced cognitive dysfunction. Cell 150:1055-1067. https://doi.org/10. 1016/j.cell.2012.06.052

37. Maggi L, Scoto M, Cirak S, Robb SA, Klein A, Lillis S, Cullup T, Feng L, Manzur AY, Sewry CA et al (2013) Congenital myopathies-clinical features and frequency of individual subtypes diagnosed over a 5 -year period in the United Kingdom. Neuromuscul Disord 23:195-205. https://doi.org/ 10.1016/.nmd.2013.01.004

38. Marks AR (2013) Calcium cycling proteins and heart failure: mechanisms and therapeutics. J Clin Investig 123:46-52. https://doi.org/10.1172/JCl62 834

39. Marks AR (2003) A guide for the perplexed: towards an understanding of the molecular basis of heart failure. Circulation 107:1456-1459

40. Marks AR (2002) Ryanodine receptors, FKBP12, and heart failure. Front Biosci 7:d970-977

41. Marks AR, Marx SO, Reiken S (2002) Regulation of ryanodine receptors via macromolecular complexes: a novel role for leucine/isoleucine zippers. Trends Cardiovasc Med 12:166-170

42. Marx SO, Gaburjakova J, Gaburjakova M, Henrikson C, Ondrias K, Marks AR (2001) Coupled gating between cardiac calcium release channels (ryanodine receptors). Circ Res 88:1151-1158

43. Marx SO, Ondrias K, Marks AR (1998) Coupled gating between individual skeletal muscle $\mathrm{Ca} 2+$ release channels (ryanodine receptors). Science 281:818-821

44. Marx SO, Reiken S, Hisamatsu Y, Gaburjakova M, Gaburjakova J, Yang YM, Rosemblit N, Marks AR (2001) Phosphorylation-dependent regulation of ryanodine receptors: a novel role for leucine/isoleucine zippers. J Cell Biol 153:699-708

45. Marx SO, Reiken S, Hisamatsu Y, Jayaraman T, Burkhoff D, Rosemblit N, Marks AR (2000) PKA phosphorylation dissociates FKBP12.6 from the calcium release channel (ryanodine receptor): defective regulation in failing hearts. Cell 101:365-376

46. Meissner G (1984) Adenine nucleotide stimulation of Ca2+-induced $\mathrm{Ca} 2+$ release in sarcoplasmic reticulum. J Biol Chem 259:2365-2374

47. Meissner G (1994) Ryanodine receptor/Ca2 + release channels and their regulation by endogenous effectors. Annu Rev Physiol 56:485-508. https://doi.org/10.1146/annurev.ph.56.030194.002413

48. Meissner $\mathrm{G}$ (2017) The structural basis of ryanodine receptor ion channel function. J Gen Physiol 149:1065-1089. https://doi.org/10.1085/jgp.20171 1878

49. Moore CP, Rodney G, Zhang JZ, Santacruz-Toloza L, Strasburg G, Hamilton SL (1999) Apocalmodulin and Ca2+ calmodulin bind to the same region on the skeletal muscle Ca2+ release channel. Biochemistry 38:85328537. https://doi.org/10.1021/bi9907431

50. Popova OB, Baker MR, Tran TP, Le T, Serysheva II (2012) Identification of ATP-binding regions in the RyR1 $\mathrm{Ca}(2)(+)$ release channel. PLOS ONE 7:e48725. https://doi.org/10.1371/journal.pone.0048725

51. Porter Moore C, Zhang JZ, Hamilton SL (1999) A role for cysteine 3635 of RYR1 in redox modulation and calmodulin binding. J Biol Chem 274:36831-36834

52. Reiken S, Lacampagne A, Zhou H, Kherani A, Lehnart SE, Ward C, Huang F, Gaburjakova M, Gaburjakova J, Rosemblit N et al (2003) PKA phosphorylation activates the calcium release channel (ryanodine receptor) in skeletal muscle: defective regulation in heart failure. J Cell Biol 160:919-928

53. Rodney GG, Williams BY, Strasburg GM, Beckingham K, Hamilton SL (2000) Regulation of RYR1 activity by $\mathrm{Ca}(2+)$ and calmodulin. Biochemistry 39:7807-7812

54. Rosemblit N, Moschella MC, Ondriasa E, Gutstein DE, Ondrias K, Marks AR (1999) Intracellular calcium release channel expression during embryogenesis. Dev Biol 206:163-177

55. Rossi D, Bencini C, Maritati M, Benini F, Lorenzini S, Pierantozzi E, Scarcella AM, Paolini C, Protasi F, Sorrentino V (2014) Distinct regions of triadin are required for targeting and retention at the junctional domain of the sarcoplasmic reticulum. Biochem J 458:407-417. https://doi.org/10.1042/ BJ20130719
56. Santulli G, Marks AR (2015) Essential roles of intracellular calcium release channels in muscle, brain, metabolism, and aging. Curr Mol Pharmacol 8:206-222

57. Santulli G, Pagano G, Sardu C, Xie W, Reiken S, D'Ascia SL, Cannone M, Marziliano N, Trimarco B, Guise TA et al (2015) Calcium release channel RyR2 regulates insulin release and glucose homeostasis. J Clin Investig 125:4316. https://doi.org/10.1172/JCl84937

58. Seo M-D, Velamakanni S, Ishiyama N, Stathopulos PB, Rossi AM, Khan SA, Dale P, Li C, Ames JB, Ikura M et al (2012) Structural and functional conservation of key domains in InsP3 and ryanodine receptors. Nature 483:108-112. https://doi.org/10.1038/nature10751

59. Shan J, Betzenhauser MJ, Kushnir A, Reiken S, Meli AC, Wronska A, Dura M, Chen BX, Marks AR (2010) Role of chronic ryanodine receptor phosphorylation in heart failure and beta-adrenergic receptor blockade in mice. J Clin Investig 120:4375-4387. https://doi.org/10.1172/JCI37649

60. Shan J, Kushnir A, Betzenhauser MJ, Reiken S, Li J, Lehnart SE, Lindegger $\mathrm{N}$, Mongillo M, Mohler PJ, Marks AR (2010) Phosphorylation of the ryanodine receptor mediates the cardiac fight or flight response in mice. J Clin Investig 120:4388-4398. https://doi.org/10.1172/JCl32726

61. Sharma P, Ishiyama N, Nair U, Li W, Dong A, Miyake T, Wilson A, Ryan T, MacLennan DH, Kislinger T et al (2012) Structural determination of the phosphorylation domain of the ryanodine receptor. FEBS J 279:39523964. https://doi.org/10.1111/j.1742-4658.2012.08755.x

62. Snoeck M, van Engelen BG, Kusters B, Lammens M, Meijer R, Molenaar JP, Raaphorst J, Verschuuren-Bemelmans CC, Straathof CS, Sie LT et al (2015) RYR1-related myopathies: a wide spectrum of phenotypes throughout life. Eur J Neurol 22:1094-1112. https://doi.org/10.1111/ene.12713

63. Sonnleitner A, Fleischer S, Schindler H (1997) Gating of the skeletal calcium release channel by ATP is inhibited by protein phosphatase 1 but not by Mg2+. Cell Calcium 21:283-290

64. Sudhof TC (2012) Calcium control of neurotransmitter release. Cold Spring Harb Perspect Biol 4:a011353. https://doi.org/10.1101/cshpe rspect.a011353

65. Tencerova B, Zahradníková A, Gaburjakova J, Gaburjakova M (2012) Luminal Ca2 + controls activation of the cardiac ryanodine receptor by ATP. J Gen Physiol 140:93-108. https://doi.org/10.1074/jbc.272.37.23389

66. Tripathy A, Xu L, Mann G, Meissner G (1995) Calmodulin activation and inhibition of skeletal muscle $\mathrm{Ca} 2+$ release channel (ryanodine receptor). Biophys J 69:106-119

67. Tung C-C, Lobo PA, Kimlicka L, Van Petegem F (2010) The amino-terminal disease hotspot of ryanodine receptors forms a cytoplasmic vestibule. Nature 468:585-588. https://doi.org/10.1038/nature09471

68. Waning DL, Mohammad KS, Reiken S, Xie W, Andersson DC, John S, Chiechi A, Wright LE, Umanskaya A, Niewolna M et al (2015) Excess TGF-beta mediates muscle weakness associated with bone metastases in mice. Nat Med 21:1262-1271. https://doi.org/10.1038/nm.3961

69. Wehrens XH, Lehnart SE, Huang F, Vest JA, Reiken SR, Mohler PJ, Sun J, Guatimosim S, Song LS, Rosemblit N et al (2003) FKBP12.6 deficiency and defective calcium release channel (ryanodine receptor) function linked to exercise-induced sudden cardiac death. Cell 113:829-840

70. Wehrens XH, Lehnart SE, Reiken SR, Marks AR (2004) Ca2+/calmodulindependent protein kinase II phosphorylation regulates the cardiac ryanodine receptor. Circ Res 94:e61-70

71. Xiong L, Zhang J-Z, He R, Hamilton SL (2006) A Ca2+-binding domain in RyR1 that interacts with the calmodulin binding site and modulates channel activity. Biophys J 90:173-182. https://doi.org/10.1529/biophysj. 105.066092

72. Xu L, Chirasani VR, Carter JS, Pasek DA, Dokholyan NV, Yamaguchi N, Meissner G (2018) Ca(2+)-mediated activation of the skeletal-muscle ryanodine receptor ion channel. J Biol Chem 293:19501-19509. https:// doi.org/10.1074/jbc.RA118.004453

73. Yan Z, Bai X-C, Yan C, Wu J, Li Z, Xie T, Peng W, Yin C-C, Li X, Scheres SHW et al (2015) Structure of the rabbit ryanodine receptor RyR1 at near-atomic resolution. Nature 517:50-55. https://doi.org/10.1038/natur e14063

74. Yuan Q, Chen Z, Santulli G, Gu L, Yang ZG, Yuan ZQ, Zhao YT, Xin HB, Deng KY, Wang SQ et al (2014) Functional role of Calstabin2 in age-related cardiac alterations. Sci Rep 4:7425. https://doi.org/10.1038/srep07425 
75. Yuchi Z, Yuen SMWK, Lau K, Underhill AQ, Cornea RL, Fessenden JD, Van Petegem F (2015) Crystal structures of ryanodine receptor SPRY1 and tandem-repeat domains reveal a critical FKBP12 binding determinant. Nat Commun 6:7947. https://doi.org/10.1038/ncomms8947

76. Zalk R, Clarke OB, des Georges A, Grassucci RA, Reiken S, Manica F, Hendrickson WA, Frank J, Marks AR (2015) Structure of a mammalian ryanodine receptor. Nature 517:44-49. https://doi.org/10.1038/nature13950

77. Zalk R, Lehnart SE, Marks AR (2007) Modulation of the ryanodine receptor and intracellular calcium. Annu Rev Biochem 76:367-385. https://doi.org/ 10.1146/annurev.biochem.76.053105.094237
78. Zhang JZ, Wu Y, Williams BY, Rodney G, Mandel F, Strasburg GM, Hamilton SL (1999) Oxidation of the skeletal muscle Ca2 + release channel alters calmodulin binding. Am J Physiol 276:C46-53

\section{Publisher's Note}

Springer Nature remains neutral with regard to jurisdictional claims in published maps and institutional affiliations.
Ready to submit your research? Choose BMC and benefit from:

- fast, convenient online submission

- thorough peer review by experienced researchers in your field

- rapid publication on acceptance

- support for research data, including large and complex data types

- gold Open Access which fosters wider collaboration and increased citations

- maximum visibility for your research: over 100M website views per year

At BMC, research is always in progress.

Learn more biomedcentral.com/submissions 